-Short communication

\title{
FUSARIUM MERISMOIDES CORDA. - A NEW RECORD OF ANAMORPHIC FUNGUS FOR BANGLADESH
}

\author{
SHAMIM SHAMSI* AND MD. DELWAR HOSEN \\ Department of Botany, University of Dhaka, Dhaka 1000, Bangladesh
}

Key words: Anamorphic fungus, Fusarium merismoides, New record, Sesame

Fusarium merismoides Corda has been described and illustrated in the present paper as a new anamorphic fungus record for Bangladesh. The fungus was isolated from sesame seeds and was reported to be pathogenic.

Recently, the authors isolated the fungus on seeds of sesame (BARI Til-3 variety). Sesame (Sesamum indicum L.) belongs to the family Pedaliaceae. Sesame is an important source of oil and protein (Kaul 1986). Sesame is grown for its edible seeds, which are the source of sesame oil used in salad and as cooking oil, lubricant and illuminant, as a vehicle for medicinal drugs and also used in confectionary. The oil cake which is rich in protein is an excellent food for livestock, and also curried in certain parts of India (Burkill 1935).

From infected seed of sesame $F$. merismoides was isolated following "Tissue planting" method (Tuite 1969) on PDA medium. Species determination was made following Booth (1971). Isolated fungus was tested for their pathogenic potentiality following seed inoculation technique (Shamsi 1999).

Fusarium merismoides Corda Icones fungorum 2:4, 1838.

Colonies cottony (Fig. 1), whitish, reverse peach to ochraceous, showed growing rate $0.9 \mathrm{~cm}$, mycelium profusely branched septate, sparse felted to pinkish mycelium with a white fringe at the growing front. Phialides hyaline (Fig. 2), $2.8-8.8 \times 1.6-2.0 \mu \mathrm{m}$. Microconidia (Fig. 2) hyaline, subcircular to fulcate $3.6-8.2 \times 1.6-2.0 \mu \mathrm{m}$. Macroconidia formed on conidiophores or formed in simple lateral phialides from the hyphae, which may remain aseptate for some time but generally develop 3 - 4 transverse septa when fully mature, $30-45 \times 3.5-5 \mu \mathrm{m}$. Chlamydospores not observed.

Species examined: Isolated from the seeds of Sesamum indicum (BARI Til-3 variety), BARI, Joydebpur, Gazipur, Dhaka. 15 September 2015.

\footnotetext{
* Corresponding author: <prof.shamsi@gmail.com>.
} 


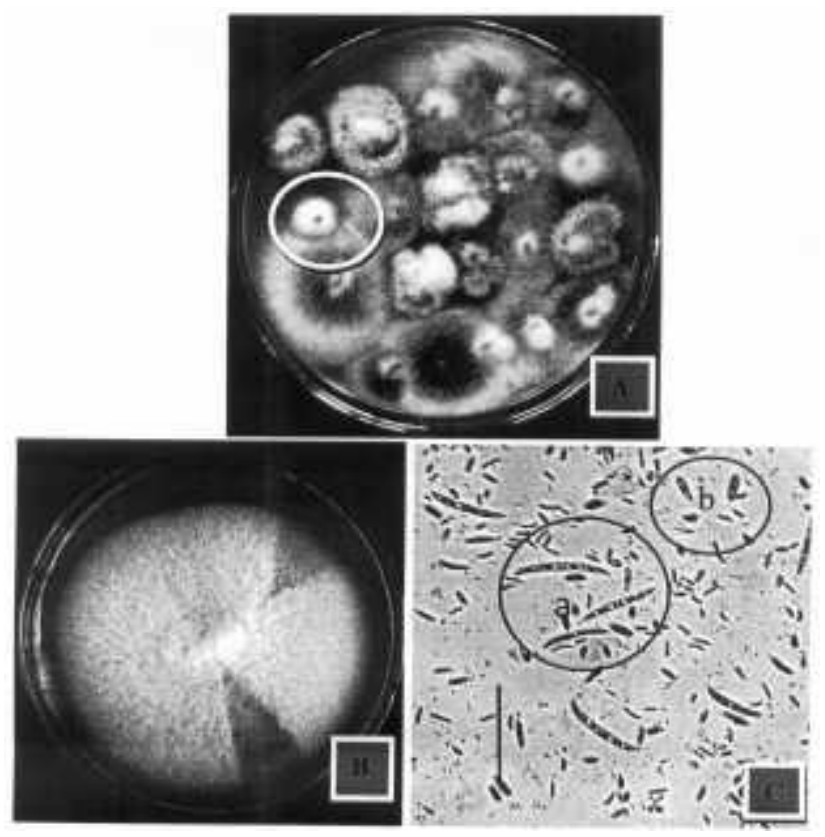

Fig. 1. Fusarium merismoides: A. Colony on sesame seed. B. colony on PDA medium. C. Macro (a) and micro (b) conidia (Bar $=50 \mu \mathrm{m})$.

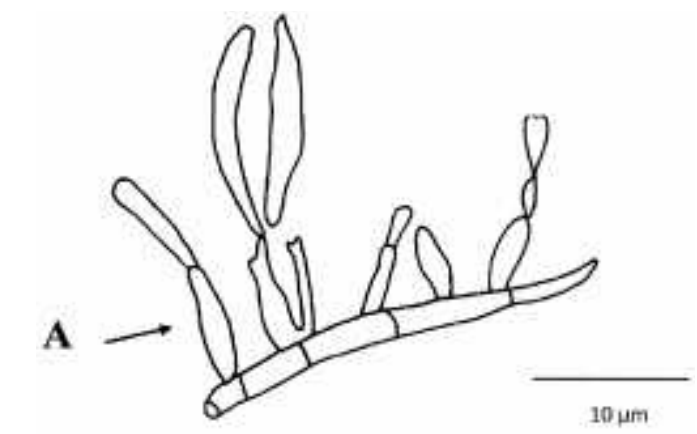

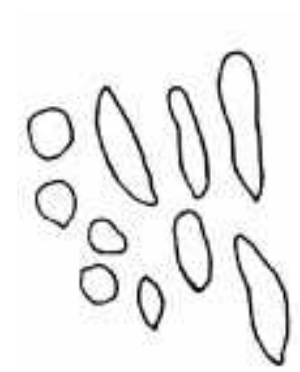

B

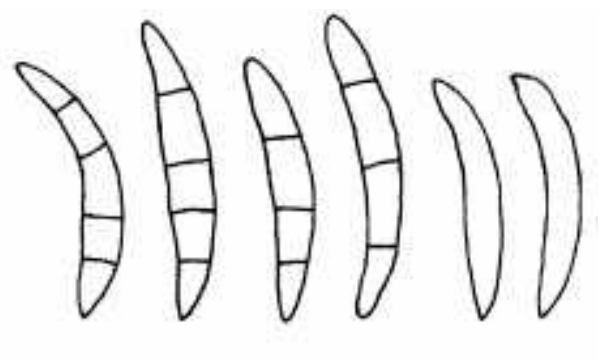

C

Fig. 2. Fusarium merismoides: A. Phialide, B. Microconidia, C. Macroconidia. 
Based on these morphological characteristics, the fungus associated with sesame seeds was identified as Fusarium merismoides. This fungus is a new record for Bangladesh as well as this is the first record of association of the fungus with sesame.

F. merismoides is fairly common in soil and polluted water or sludge. In Finland the fungus was reported from stored potatoes. The fungus was also reported as plant pathogen (Booth 1971).

\section{REFERENCES}

Booth, C. 1971. The genus Fusarium. The Commonwealth Mycological Institute, England. pp. 267. Burkill, I.H. 1935. Dictionary of Economic Products of Malay Peninsula, Vols 1 \& 2. London. pp. xi, [i, blank], 1220; [iv], 1221-2402, [2].

Kaul, A. K. 1986. Oilseeds in Bangladesh. Bangladesh-Canada Agriculture Sector Team, Ministry of Agriculture, Dhaka. Government of the People's Republic of Bangladesh. Dhaka. p. 38.

Shamsi, S. 1999. Investigations into the sheath rot disease of rice (Oryza sativa L.) in Bangladesh. Ph.D. thesis. Department of Botany, DU, Dhaka. Bangladesh. pp. i - vii + 132

Tuite, J. 1969. Plant Pathological methods. Fungi and Bacteria. Minneapolis, Minnesota. USA. Burgess Publishing Company. pp. 239. 